\title{
Memory and place on the Liverpool waterfront in the mid-twentieth century
}

\author{
LAURA BALDERSTONE, GRAEME J. MILNE and \\ RACHEL MULHEARN \\ School of Histories, Languages and Cultures, University of Liverpool, \\ 9 Abercromby Square, Liverpool L69 7WZ, UK \\ School of Histories, Languages and Cultures, University of Liverpool, \\ 9 Abercromby Square, Liverpool L69 7WZ, UK \\ Rachel Mulhearn Associates, 11 Menlove Gardens West, Liverpool, L18 2DL, UK
}

\begin{abstract}
This article explores the changing urban form and society of waterfront Liverpool in the last generation of the city's role as a traditional general cargo seaport. Deriving much of its evidence from a collaborative public history project, it demonstrates the continuing vitality of the near waterfront zone into the 1960s, and interprets the subsequent sudden collapse of the district with the closure of the south docks in 1972. Interviewees identified sites of memory that cast light on both the routine working of the district and the nature of its fall into dereliction and abandonment.
\end{abstract}

The regeneration of waterfront districts has grown into a global phenomenon since the 1980s, but is just the latest phase of a much older concern for the problematic spaces that characterized historic seaports. Long-associated with transience, drink, prostitution and crime, the urban waterfront has been a place of great tension and conflict. If casually employed dock labourers and itinerant seafarers had to live near the wharves and docks, those same spaces were also needed for the offices, processing plants, warehouses and state institutions of globalizing economies. People across a broad social spectrum shared in suffering what Lewis Mumford called 'long-festering waterfront areas'. ${ }^{1}$

When Mumford wrote that at the beginning of the 1960s, he was signalling a potential transformation of Europe's seaport cities. Post-war planners hoped that bombed waterfronts would be the blank canvas for new cityscapes. However, traditional patterns of cargo-handling, passenger liner services and maritime commerce persisted in the central districts of many seaports through the 1950s and 1960s, before finally being defeated by air travel and containerization in the 1970s. That last

1 L. Mumford, The City in History (Harmondsworth, 1966), 479. 
generation of the old urban waterfront has therefore become an important subject for research, revealing the tensions between the planners' drive for clearance and reconstruction, and the continuing needs of the maritime economy and society. ${ }^{2}$

This article explores some of these issues using Liverpool as a case-study, and draws largely on oral history research conducted by the Arts and Humanities Research Council funded Mapping Memory on the Liverpool Waterfront project. ${ }^{3}$ It identifies and interprets key 'sites of memory', with a particular concern to explore the continuing maritime character of the streets behind the central docks, and the extent to which people were conscious of, or influenced by, the area's older seafaring heritage. The article begins with a discussion of the conceptual underpinning of the research and an explanation of its methodology, providing context for the main sections, which assess a variety of indicators of memory, heritage and identity in what was once one of the world's most notorious 'sailortown' districts. $^{4}$

\section{Sites of memory}

There is now a considerable body of literature on the related topics of public and collective memory, heritage, place-consciousness and place-identity. Academics in various disciplines contribute to this, most obviously historians, geographers, sociologists, planners and environmental psychologists..$^{5}$ The range and richness of work in the field helped focus and interpret the research that underpins this article, despite and because of important differences between the approaches adopted here and some of the broader priorities evident in the literature.

Much of the existing work on memory and place focuses on traumatic events, and usually on the major conflicts of the twentieth century. Without belittling the troubles of individuals and communities in changing waterfront districts, these are obviously on a different scale from

2 D. Hilling, 'Socio-economic change in the maritime quarter: the demise of sailortown', in B.S. Hoyle, D.A. Pinder and M.S. Husain (eds.), Revitalising the Waterfront: International Dimensions of Dockland Redevelopment (London, 1988), 20-37; N. Falk, 'Turning the tide: British experience in regenerating urban docklands', in B.S. Hoyle (ed.), European Port Cities in Transition (London, 1992), 117-36.

${ }^{3}$ The authors wish to thank the Arts and Humanities Research Council for funding this project as part of the Beyond Text research programme. We are grateful to other Beyond Text grantholders for advice and comments, but most particularly to Professor Evelyn Welch and Ruth Hogarth, Director and Research Coordinator for Beyond Text. See www.liverpoolmuseums.org.uk/mappingmemory.

${ }^{4}$ G.J. Milne, 'Maritime city, maritime culture? Representing Liverpool's waterfront districts since the mid-nineteenth century', in M. Benbough-Jackson and S. Davies (eds.), Merseyside: Culture and Place (Newcastle upon Tyne, 2011), 88-108.

5 A. Confino, 'Collective memory and cultural history: problems of method', American Historical Review, 102 (1997), 1386-403; G. Cubitt, History and Memory (Manchester, 2007); M. Lewicka, 'Place attachment: how far have we come in the last 40 years?', Journal of Environmental Psychology, 31 (2011), 207-30; P.C. Adams, S. Hoelscher and K.E. Till (eds.), Textures of Place: Exploring Humanist Geographies (Minneapolis, 2001). 
experiences of World War II, the Holocaust, Apartheid or major natural disasters, which inform most recent writing. ${ }^{6}$ In addition, one of the field's fundamental texts, Pierre Nora's conceptualization of 'lieux de mémoire', was a study of national and communal memorialization, and this has set the framework for much subsequent writing. ${ }^{7}$ While often translated as 'sites of memory', scholars have noted that 'site' is too literally spatial for Nora's meaning, which is perhaps better captured by words like 'realm'. ${ }^{8}$ It is also important that much of the discussion of historical place-identity relates to memorials, buildings and spaces that have been deliberately constructed or adapted for their historical and cultural symbolism.

Shifting the focus of investigation toward a narrower definition of 'site' allows us to explore the interconnection of public memory with placeconsciousness at a more local level. Cities, with their complicated mix of stability and upheaval over time, have become important laboratories for such research. ${ }^{9}$ When studied at this scale, many people identify sites of memory that are not formal memorials, but ordinary urban spaces, buildings and places. It becomes possible to interpret urban change through the memories and associations of city-dwellers down to a fine grain, while also retaining a wider sense of adaptation to external forces. Work on the decline of industrial districts is particularly relevant here, notably Alice Mah's studies of Tyneside and Talja Blokland's study of Rotterdam. ${ }^{10}$ As will be discussed, however, concepts of post-industrial society and deindustrialization can sit awkwardly with the history of seaport cities that lacked a strong manufacturing sector.

It is against this background that the Mapping Memory project sought to identify and interpret the key 'sites of memory' for people who lived and worked in the waterfront zone of the 1950s and 1960s. The project focused on south-central Liverpool, an area with a particularly dislocated history in the twentieth century. Stretching from the central business and shopping districts southward along the line of the docks, this was a densely populated strip at the heart of the working port, with a characteristic jumble of retail, wholesale, distributive, industrial and residential uses. Although less prominent in the literature than the infamous slums of north Liverpool, this district shared many of their characteristics of poor

${ }^{6}$ For example, K.L. Klein, 'On the emergence of memory in historical discourse', Representations, 69 (2000), 127-50; S. Hoelscher and D.H. Alderman, 'Memory and place: geographies of a critical relationship', Social and Cultural Geography, 5 (2004), 347-55.

7 P. Nora, 'Between memory and history: les lieux de mémoire', Representations, 26 (1989), $7-25$.

8 T. Judt, 'A la recherche du temps perdu', New York Review of Books, 3 Dec. 1998, 51-8.

${ }^{9}$ For example, D. Glassberg, 'Public history and the study of memory', Public Historian, 18 (1996), 7-23; C.M. Boyer, The City of Collective Memory: Its Historical Imagery and Architectural Entertainment (Cambridge, MA, 1996).

10 A. Mah, 'Memory, uncertainty and industrial ruination: Walker Riverside, Newcastle upon Tyne', International Journal of Urban and Regional Research, 34 (2010), 398-413; T. Blokland, 'Bricks, mortar, memories: neighbourhood and networks in collective acts of remembering', International Journal of Urban and Regional Research, 25 (2001), 268-83. 
housing, casual employment and transient populations. ${ }^{11}$ It has often been represented as a maritime space, with Paradise Street long-established as a sailors' quarter, while Park Lane and its surrounding streets commonly appear in early twentieth-century testimony as home to a multinational population of seafarers, their families and associates. ${ }^{12}$

Very few buildings survive in this area from before 1939, although by accident those that do are broadly representative of important uses. The former Gordon Smith Institute for Seamen, the Scandinavian church and the Baltic Fleet pub are all in their different ways symbols of the 'sailortown' phenomenon. Joseph Heap's rice mill represents the large processing works that used to be found near the waterfront, while some nineteenth-century warehouses survive in blocks between Jamaica Street and St James's Street. The major building form that is now almost completely absent is the two- or three-storey 'Georgian' terrace, often combining residential and small business uses, that lined many of the streets - the side streets around Duke Street and Parr Street, slightly further inland, give the closest surviving impression of a once general pattern. In addition, much of the public housing constructed in the midtwentieth century has since been demolished, and parts of the area have been cleared and redeveloped twice since 1945: the whole district behind the south-central docks consisted of 'Areas of obsolescence' or 'Housing areas presenting environmental problems', according to the classification adopted by the 1965 city plan. ${ }^{13}$

The project encouraged public engagement and participation through group mapping workshops and individual interviews. People gathered round a table-sized street map, annotating it with notes and drawings to identify locations that had been in some way important to them, and to situate those places in time. Archive photographs were brought to the sessions, and participants often used these as markers of key points in space and in time, to explain sequences of events and cycles of dereliction and reconstruction. ${ }^{14}$

The base map itself was crucial to this process, in a revealing way that required an early change to the project's working practices. Initially, a diagrammatic map based on the current street plan was used in the expectation that interviewees would orient themselves readily, and that the locations they identified could then be transposed onto older street

${ }^{11}$ C.G. Pooley, 'Living in Liverpool', in J. Belchem (ed.), Liverpool 800: Character, Culture and History (Liverpool, 2006), 171-256.

12 S. Hugill, Sailortown (London, 1967), 95-113; P. O'Mara, The Autobiography of a Liverpool-Irish Slummy (London, 1934), 11-14.

13 D.M. Muchnick, Urban Renewal in Liverpool: A Study in the Politics of Redevelopment (London, 1970), 62-5; see the 'Appraisal map' in Liverpool City Centre Planning Group, Liverpool City Centre Plan (Liverpool, 1965), 50.

14 The project is grateful to the Liverpool Record Office and to the Maritime Archives, National Museums Liverpool, for the use of these images, many of which have now been built into the Mapping Memory website. 
Mersey Chambers -

Harrison Line HQ

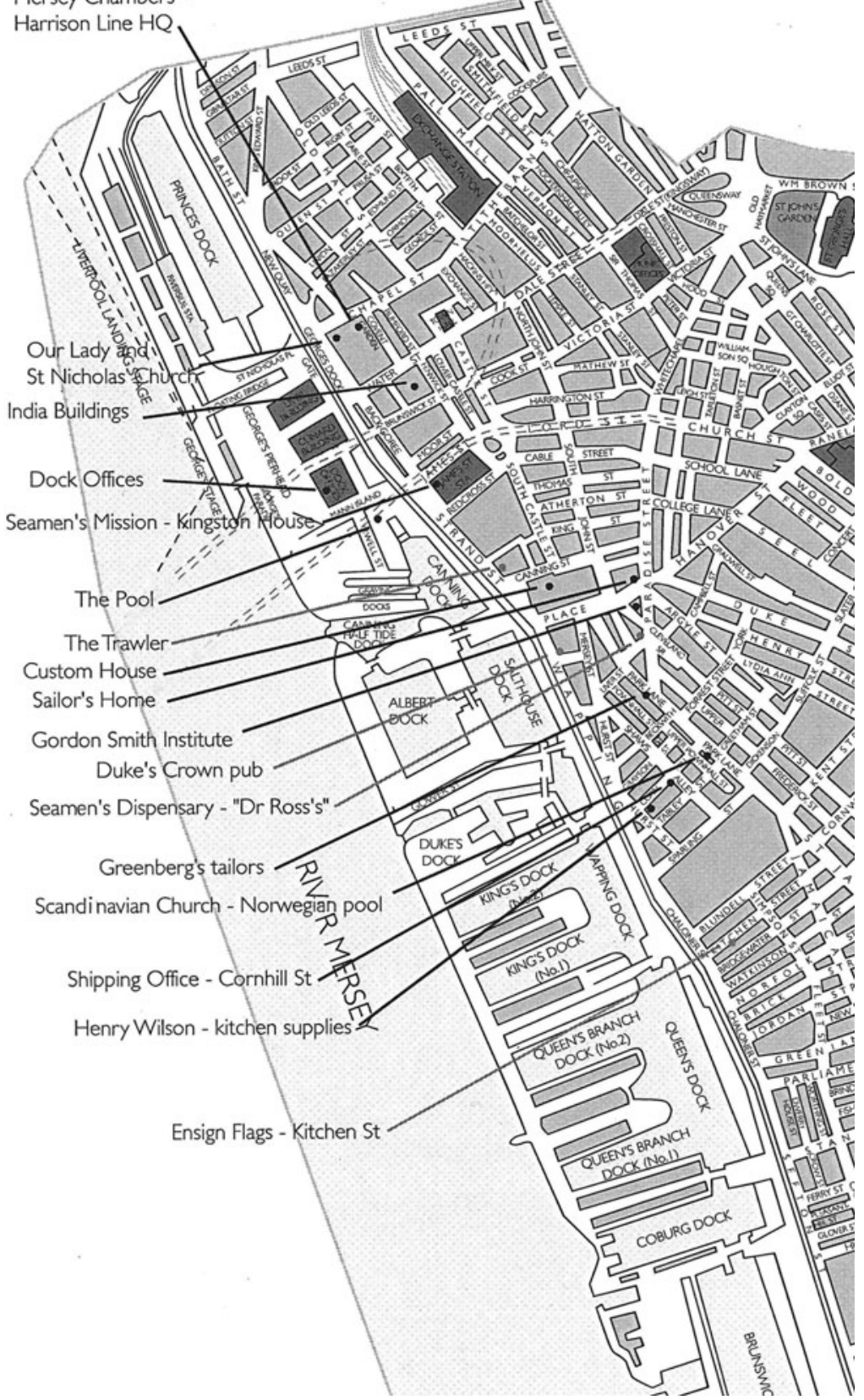

Figure 1: Sites of memory identified during group workshop with retired seafarers 
patterns during the interpretation phase. However, it quickly emerged that participants were more comfortable navigating around former street plans rather than the current one, and that some had spent little time in the recently redeveloped parts of the district. They were, in effect, getting lost in the current cityscape, despite their intimate knowledge of the area. The project team therefore devised a map based on the 1950s street plan. This map, combined with the archive photographs, allowed the participants to re-enter virtually 'their' Liverpool, and to discuss and debate comparisons with the current urban layout. Importantly, the workshops and interviews were all filmed, enabling the material to be viewed subsequently in all its multi-media and interactive aspects. Simply audio-recording the sessions would have created a much inferior record of the research process, and would in particular have missed the interviewees' interaction with the map and, by extension, with the past and present space. ${ }^{15}$

The project team tried to engage a range of interviewees in terms of age, gender and occupation. We also sought to mix the format of our public sessions, combining workshops attended by existing groups with open public drop-in sessions and individual interviews. The two formal workshops involved a women's history group (14 participants) and a group of five retired seafarers, both initially contacted through National Museums Liverpool. The former gave us access to the often neglected voices of women in a seaport city, while providing a broad age-range from 60 to 95, with a consequent mix of childhood and adult recollections. In both workshops, established relationships allowed the group to share memories with very little ice-breaking.

The two drop-in sessions were an attempt to engage people who might not otherwise encounter academic research projects. One was held in a café just off Park Lane, which until the 1970s was a busy thoroughfare just inland of the waterfront, the other in the event space of Radio Merseyside's building on Hanover Street. The Park Lane session produced a highly detailed and very local map, but participants were less inclined to leave more extended testimony about their own experiences. In contrast, the Radio Merseyside session produced a series of detailed personal narratives from people who had no previous connection with one another or the project. Although common in other disciplines and contexts, group workshops and drop-in sessions have been used less often by historians, and the experience of this project suggests that they are an effective means of securing public participation, and of mixing the memories of individuals

${ }^{15}$ For more detail on the project's methods, see L. Balderstone, G.J. Milne and R. Mulhearn, 'Collecting the Liverpool waterfront: recollections and collections', Museum and Society, forthcoming; many video extracts are on the Mapping Memory website. Transcripts and other project materials are available for researchers to use at the Maritime Archives, National Museums Liverpool. 
with the collective response of both established groups and strangers. ${ }^{16}$ It probably helped that the drop-in sessions were hosted in trusted local venues rather than being run in an academic or educational space.

Some of the workshop and drop-in participants were then approached for more detailed individual interviews, and they in turn offered further contacts. The project team ran 19 in-depth interviews with 22 participants (14 men and 8 women), including people who had experienced the district as a barmaid, an electrician, a rigger, a police officer, office workers, a hat maker, a nautical engineer, a banana ripener, an architect and a student. The interviews, like the workshops, focused on the base map and archive images, and generated substantial testimony from a striking variety of perspectives.

A number of themes emerged from the workshops and interviews, and the remaining sections of this article consider the most revealing of these. The unifying threads have to do with the interconnected nature of longestablished urban districts, and the often sudden abandonment of places in response to external changes. Waterfront Liverpool was an old urban place, with the sort of intermingled and interdependent society and economy that can only develop during centuries of specialization and co-operation. At the same time, the components of that society - people, families, small firms - could be highly individualistic. The mapping technique showed that our interviewees' mental boundaries varied dramatically from one another. While they all began talking about a small area of waterfront Liverpool (often the Pierhead), the plotted sites on their final memory maps clustered in a wide range of different ways. The mapping process captured conflicting feelings of optimism, pessimism and nostalgia as shifting focal points in the memories of individuals, which often did not adhere to a simple linear progression through time.

\section{Recovery and persistence}

The first, and very pervasive, perception emerging from the interviews was that large parts of waterfront Liverpool were abandoned and neglected for too long after World War II. It is important to assess the chronology of this feeling, however, because there were two distinct phases. Central Liverpool still had many empty spaces and damaged buildings in the 1950s and even the 1960s, and there was general frustration at the lethargy and incompetence of those responsible for rebuilding in the aftermath of the Blitz. This was tempered by an underlying thread of optimism in the continuing life of the city, and a sense that the maritime-oriented economy was recovering and even thriving amid the rubble. There is then a clear break in the testimony, with the ruined Liverpool of the 1970s and 1980s

16 M. Bloor, J. Frankland, M. Thomas and K. Robson, Focus Groups in Social Research (London, 2001); R.A. Kreuger and M.A. Casey, Focus Groups: A Practical Guide for Applied Research (London, 2000); L. Abrams, Oral History Theory (London, 2010), 79. 
recessions being seen as a very different kind, and scale, of abandonment; that phase will be the subject of a later section.

War damage inevitably had a lasting impact on Liverpool and its people. As well as the docks themselves, key buildings, streets and spaces were wholly or partly destroyed, most notably the Custom House and the warren of sailortown bars, small workshops and warehouses around South Castle Street, Paradise Street and Park Lane. ${ }^{17}$ Once the debris was cleared, many of these sites remained empty. A Times correspondent wrote in 1963 that 'for 20 years the centre of Liverpool has been like the belly of some mangy stuffed animal in a Victorian museum. Great bald patches caused by bombing serve as temporary car parks; beyond the centre the slums stretch away behind the docks to north and south.' Liverpudlians had become sceptical, he claimed, and while some headline schemes were finally making progress, it was vital that momentum be maintained so that people should not feel that they were 'again being let down'. ${ }^{18}$

Younger interviewees remembered the city centre as a playground, full of open spaces, rubble, ruins and monumental dock infrastructure to climb on. The site of the Custom House, damaged in the war and then demolished in the late 1940s, was not filled in for years afterward, and its ruined foundations became a playground. ${ }^{19}$ The building's cellars were open to the sky and formed a labyrinth for war games. One interviewee, who had a German surname thanks to his Prussian grandfather, remembered always having to play the Nazi in these battles. ${ }^{20}$ Children imposed their own meanings on the ruins to suit their games, interpreting the barred windows as cells that once housed smugglers, whereas in reality they were designed to keep people out rather than in. ${ }^{21}$

Interviewees who knew the city as adults in this era also recalled the patchwork of bombed sites, isolated surviving buildings and temporary attempts at infill. Coronation Gardens, a small park created in the 1950s, was a favourite lunchtime resort for office and shop workers, full of the smell of geraniums, while its benches gave anyone who had missed the last bus a place to sleep. ${ }^{22}$ However, 20 years after the war, it was still a rare green space 'surrounded by a windy waste of bombed sites and parked cars'. ${ }^{23}$

Amid the painfully slow rebuilding effort, those working in a range of small firms remembered a continuing waterfront economy into the late 1960s, with a dense mix of maritime business (and its associated, characteristic, maritime busyness). City council research in the 1960s

17 J.C. Hughes, Port in a Storm: The Air Attacks on Liverpool and its Shipping in the Second World War (Birkenhead, 1993).

18 Times, 6 Apr. 1963, 9.

19 Interview with Colin.

20 Interview with Vincent.

${ }^{21}$ Interview with Colin.

22 Interviews with Colin, Di.

${ }^{23}$ Liverpool City Centre Plan, 38. 
identified about 100 industrial firms in the Wapping/Park Lane area, the triangle of land behind the south docks, including a mix of maritimeoriented works and others, particularly motor engineers, attracted by cheap premises. ${ }^{24}$ Oral history evidence allows us to reconstruct the interconnectedness of districts like this with an unusual level of clarity, something that is very hard to do from archives, because the survival rate of the routine records of small industrial businesses is vanishingly low. The result is a dense pattern of separate but closely linked sites of memory.

One of our interviewees started work as an apprentice rigger in 1963, aged 15, and had to deliver equipment to ships and to other firms by bicycle. Small companies specialized in particular goods and services, so a day's work might involve gathering different items from firms in the area, then delivering them to a ship in one of the docks. Chains had to be taken to a firm called Foxhall Palmers to be tested; the carrier bikes used for deliveries were maintained and repaired by Llewellyns on Park Lane; a firm on Duke Street polished and engraved ships' bells; metal components had to be taken to a galvanizing works behind the north docks; orders for cargo nets or fenders were discussed with a firm called Goodyear Nix and then collected a day or two later for delivery to a ship; hurricane lamps were the speciality of an old-fashioned shop on Cleveland Square. ${ }^{25}$

There was an enormous store of human capital in such districts, as one interviewee who worked in a ships' stores dealer recalled,

the reps would come in with a lump of something that I'm presuming was a piece of machinery and that would have to be either tooled up or somebody would recognize it and say 'oh, ok you want so-and-so and it's such-and-such size, we'll get onto ...'. There was an awful lot of being, not quite the middle man, but having to subcontract or suborder on specialist equipment and the men who worked on that side of the business must have been extremely knowledgeable. ${ }^{26}$

That density and knowledge allowed a plethora of tiny firms to maintain complementary niches within the broader maritime supply sector, in a classic light industrial cluster of the sort that is increasingly familiar in the business history literature. ${ }^{27}$

Importantly, however, it also required supportive urban infrastructure, enabling people to work effectively in such an environment. One of the most striking characteristics of traditional waterfront districts is the extent to which people worked long hours outside, and a variety of services grew up to support them. Dockers are the best known of the outside workers; they had to gather close to the dock entrances at the beginning of shifts, and sometimes had to wait for extended periods between jobs. Before, between

24 Ibid., 20.

25 Interview with Colin.

26 Interview with Di.

27 J. Wilson and A. Popp (eds.), Industrial Clusters and Regional Business Networks in England, 1750-1970 (Aldershot, 2003). 
and after shifts, they needed hot food and drink. Many other workers shared some of this experience. Carters and lorry drivers, messengers, police officers, postal workers and tradesmen of many kinds spent much of their working day away from base. The bustle of all this comes across in several interviews. ${ }^{28}$ In the words of one seaman, 'I remember walking down onto the Queen's Dock ... thinking how many people there were there; you'd be passing loads of people: gangs coming off work, people provisioning the ships, crews returning, it was busy, very busy. ${ }^{29}$

These workers often sought refuge in cafés and pubs. Hughes' Café on the corner of Wapping and Canning Place was busy enough to need two floors, and Stan Waters owned a chain of dock road cafés north of the Pierhead. Interviewees remembered a clientele of dock workers, carters and delivery drivers. The dock road itself was essentially a vast lorry park, because wagons were only allowed through the dock gates in small numbers; one seaman recalled that it was common for 30 or 40 lorries to have to wait at each dock gate. ${ }^{30}$ Drivers therefore spent a lot of time waiting in the cold. Carters faced a slightly different problem, in that their horse-drawn carts usually had traffic priority so could keep moving; sometimes a horse would carry on up the road unaccompanied while the carter stopped for a drink. ${ }^{31}$

Dock road cafés are remembered as warm and welcoming places serving industrial quantities of tea and toast. The ingenuity and entrepreneurial canniness of café proprietors was also clear from the production-line techniques on view at the counters: one interviewee recalled toast on a moving grill being brushed with melted butter to speed the process. ${ }^{32}$ They also had to accommodate the quirks of their customers. One former seafarer recalled that the café on the ground floor of the Kingston House seamen's mission had a man constantly mopping the floor; a room full of seamen nursing hangovers made for a lot of spilled coffee in a morning. ${ }^{33}$

Relatively little written testimony survives of the pub culture of waterfront Liverpool, although John Cornelius' memoir of the 'Lucky Bar' on Parliament Street is an important exception. ${ }^{34}$ Cornelius was well aware that such sailortown bars with their transient clientele of visiting mariners turning up at all hours were a disappearing phenomenon, even before his particular example was bulldozed to make way for the city's inner motorway scheme. Dock road pubs were places of entertainment as well as drink, and interviewees remembered a great deal of live music, even during the day: 'it was like a night out every lunch time'. ${ }^{35}$ Their routines

${ }^{28}$ Interviews with Colin, Rita, John.

${ }^{29}$ Interview with Tony.

${ }^{30}$ Workshop with seamen.

${ }^{31}$ Interview with Colin.

32 Interview with Ian.

${ }^{33}$ Interview with Tony.

34 J. Cornelius, Liverpool 8 (Liverpool 1982), 55-73.

35 Interview with Tony. 
were also timed to the rhythms of shifts on the docks, with a particularly busy lunchtime period: in one pub 'at 12 o'clock they used to put like 12, 14 pints of Guinness on a tray, just waiting for the dockers to come in. They used to have like a great big silver stick that used to go along the top and just take the head off the ale'. ${ }^{36}$

Pub culture also demonstrates the complicated place of women in the waterfront zone. Some of our female interviewees had the perception that a woman going into a pub would inevitably be mistaken for a prostitute, but others frequented pubs alone or with their friends. The docks themselves were a complex gendered space, and some women assumed that they would be stopped from entering unless accompanied by a male colleague; large numbers of other women of course worked in the docks every day, mostly in cleaning or catering jobs but also in a range of other occupations. ${ }^{37}$ Both class and spatial factors are at work here. Women who travelled into the city to work in offices and businesses had a different view of the pubs from those who lived in the district; the latter group had a local 'watering hole' where they knew everyone, but even they would probably not have gone into pubs more generally on the dock road itself. ${ }^{38}$

Other women interviewees had worked in pubs, and both men and women recalled that some of the toughest licensees were women; this was a continuation of a much older waterfront pattern of women running businesses either in their own right or while their husbands were away at sea. ${ }^{39}$ Nell Flanegan, licensee of the Custom House Hotel, was known as the Duchess of Canning Place, and continued the old tradition of giving extended credit to young sailors on the one hand and refusing to serve anyone she disliked on the other. ${ }^{40}$ The licensee of the Lisbon, on the corner of Victoria Street and Stanley Street, was remembered as a 'dead hard woman' who physically removed fighting men from her bar, but who also fired a barmaid for speaking back to sexist customers and coming out as a lesbian. ${ }^{41}$

Some key sites of memory demonstrate the continuing presence of seafarers in the city. The Sailors' Home, originally built in the 1850s to provide a refuge from the bars and brothels of sailortown, was still a landmark for mariners in the 1960s. Shipping out from there as a young seaman was a rite of passage that mariners remembered, even if they also thought the place looked like a prison. Some former mariners had mental maps populated by pubs, missions where they played snooker and

${ }^{36}$ Interview with Kevin.

37 Second Chance to Learn Project, Women's Work on the Liverpool Docks and Waterfront, 19161987 (Liverpool City College, 1987).

38 Interviews with Di, Margaret W.

${ }^{39}$ Interview with Dennis.

${ }^{40}$ Interview with Dennis; T. Wailey, 'The seamen's strike, Liverpool 1966', History Workshop Journal, 5 (1978), 111-22.

41 Interview with Sandi. 
offices where they had to sign on for their next ship. ${ }^{42}$ Other Liverpudlians were conscious of the presence of seafarers in various ways; one woman remembered a supply of exotic talcum powder and soap that came from passenger liners, while others remembered them in pubs: 'if there was ships in you'd see different sailors propping up the bar, always loud and really happy like they were made up being in Liverpool' ${ }^{43}$

Waterfront Liverpool clearly maintained many elements of a traditional seaport society well into the 1960s. Its cluster of small industrial and service firms persisted, held together by the maritime economy and the needs of the people who worked in it. Moving into the next decade, the testimony of our interviewees took a sharp turn away from maritime themes toward a much more negative set of memories.

\section{De-urbanization and displacement}

Fundamental changes hit Liverpool in the late 1960s, and had become brutal by the early 1970s. This was a second, and much more dangerous, period of abandonment. The problem then was no longer a dilatory response to war damage, but a pervasive dereliction caused by economic and industrial collapse. Containerization and air travel undermined traditional labour-intensive port activity. Almost simultaneously, many of the multi-national manufacturing firms that Merseyside had worked so hard to attract in the 1940s and 1950s retrenched in the wake of the oil shock, closing their branch factories. Liverpool's economy, employment opportunities and population shrank on most fronts. ${ }^{44}$

Contrary to broader perceptions, the maritime industries never left Merseyside, but they did leave central Liverpool. Container and bulk cargo ships demanded the long quays, deep water, cranes and open spaces of the far north docks at Bootle, rendering obsolete the compact docks surrounded by warehouses and transit sheds so characteristic of the south-central part of the Mersey system. ${ }^{45}$ With the formal closure of the south docks in 1972, the old waterfront zone lost its purpose very quickly. Consultants reporting for the Department of the Environment in 1977 noted that 'the impact of abandoned docks, empty warehouses, crumbling factories and mills and acres of derelict land add up to a form of environmental anarchy'. ${ }^{46}$ Interviewees usually remembered firms not as having closed outright, but as having moved elsewhere on Merseyside,

42 Workshop with seamen.

43 Interviews with Val, Sandi.

44 T. Cornfoot, 'The economy of Merseyside, 1945-1982: quickening decline or post-industrial change?', in W.T.S. Gould and A.G. Hodgkiss (eds.), The Resources of Merseyside (Liverpool, 1982), 14-26.

45 G.J. Milne, 'Maritime Liverpool', in Belchem (ed.), Liverpool 800, 257-310; A. Lynch, Weathering the Storm: The Mersey Docks Financial Crisis, 1970-1974 (Liverpool, 1994).

46 Department of the Environment, Change or Decay: Final Report of the Liverpool Inner Area Study (London, 1977), 43. 
and there were a lot of boarded-up buildings with signs saying things like 'moved to Aigburth' ${ }^{47}$ Many firms also tried to diversify into providing engineering and supply services to a broader range of industries, reducing their dependence on the port and its traffic. ${ }^{48}$

The Liverpool evidence therefore offers an important variation on the well-known theme of deindustrialization and the post-industrial city. The post-industrial paradigm has always sat uneasily in seaport cities, because their economies were oriented to distribution, transport and processing rather than manufacturing. Liverpool did suffer a process of de-industrialization, but only if 'industry' is defined more widely than usual. In addition, it would be more accurate to refer to a suburbanization of industry rather than a loss of it altogether; peripheral industrial estates with easy access to the newest parts of the dock system became home to a busy maritime-related complex of small firms that remains active in the twenty-first century.

Indeed, a sudden sub- and ex-urbanization is a fair characterization of what happened to the area behind the central docks in the 1970s and 1980s. With the winding-down and ultimate closure of the south docks, the district was rapidly abandoned. Flight from the city became general in the 1970s, but waterfront districts emptied fastest. Of Liverpool's 33 wards, only 2 gained any population between the censuses in 1971 and 1981, and no fewer than 12 lost more than 20 per cent of their people. Overall, Liverpool's population collapsed to half its 1930 s level by the end of the century. ${ }^{49}$

Park Lane and its surrounding streets, at the heart of the traditional maritime district, was typical of this shift. Into the 1960s, this was a busy residential and shopping area. Many people lived above shops in Georgian terraces, while the large blocks of flats in Kent Gardens ('Corpie flats' or 'tennies') housed a community big enough to support schools and public baths. Park Lane itself had a long parade of small shops as well as, in this case almost literally, 'a pub on every corner' (a frequently recurring phrase in the interviews for this project). ${ }^{50}$ One interviewee remembered only going into the city centre to buy clothes; all other shopping could be done locally on Park Lane. ${ }^{51}$

Recalling the 1970s, however, one Park Lane resident described a tragic kind of pub crawl driven by urban dereliction, having to move from one pub to another over time as they closed down:

Well once these shut down here, we started moving up the Lane didn't we ... the Lane shut down we went to the Horse Shoe didn't we. And then they shut the

47 Interviews with Di, Colin, John Q. and Stephen.

48 Interview with Ian.

49 Office of Population Census and Surveys, Census 1981, County Report: Merseyside (London, 1982).

50 Interview with Colin.

51 Interview with Margaret W. 
Horse Shoe down so we're being like moved, they're moving us further away. So as we're just moving from, once they shut one pub we moved to another pub. ${ }^{52}$

Some residents appealed to the council about the decline in the number of shops, aware that for older people the district was becoming untenable. ${ }^{53}$ By then, though, the tenement blocks (little more than a generation old in some cases) were earmarked for demolition and were being steadily emptied. These events reinforced a long-standing view in the minds of Liverpudlians about local government - planning consultants noted in 1977 an 'overriding sense of alienation amongst local people from the activities of the local authority: a deeply rooted distrust of many officials and members and a cynicism about the likely results of their activities'. ${ }^{54}$

Even here, though, the chronology is less clear-cut than is initially apparent. The Park Lane area, vibrant enough in the 1960s, was already much changed from the district it had been before World War II. This part of Liverpool was historically very mixed, socially and ethnically, home to an international array of seafarers, their descendants and families, and also to immigrants from elsewhere in Britain. ${ }^{55}$ Pat O'Mara, an early twentiethcentury witness, offered evocative descriptions of these streets divided into small national and ethnic clusters grudgingly getting along with one another. ${ }^{56}$ Pitt Street, Park Lane and the numerous nearby side streets were the focal point of both Chinese and black Liverpool before 1930s slum clearance, the Blitz and the council's rehousing strategies moved those communities south and east. Chinatown was recentred on Nelson Street, while Granby Street became an important focus for Liverpudlians of West African and Caribbean origins. Discussing this part of the city in relation to the landmarks of black Liverpool is, as Jacqueline Nassy Brown put it, taking a tour of 'places that no longer exist'. ${ }^{57}$

One of our interviewees remembered a marked change in attitudes around Park Lane after the war:

Well then the ' $\mathrm{N}$ ' word came out and things like that, you know. And I said 'Oh, all of a sudden we're "N"s now' ... I hate that word that's why I won't say it! ... I've even been called some horrific names for no reason because I just passed somebody and I thought 'my God, where's all this friendliness from the war gone?'58

Indeed, Liverpool's black citizens have a very pronounced sense of the different spaces in their city, and one that suggests yet another layering of

52 Workshop at Doreen's café.

${ }^{53}$ Interview with Margaret W.

54 Change or Decay, 17.

55 R. Costello, Black Salt: Seafarers of African Descent on British Ships (Liverpool, 2012); D. Frost, Work and Community among West African Migrant Workers since the Nineteenth Century (Liverpool, 1999).

56 O'Mara, Autobiography.

57 J.N. Brown, Dropping Anchor, Setting Sail: Geographies of Race in Black Liverpool (Princeton, 2005), 2; S. Craggs and I.L. Lynn, A History of the Chinese Community (Liverpool, 1985).

58 Interview with Margaret W. 
boundaries and sites of memory that can be very different depending on perspective. ${ }^{59}$ One interviewee recalled that 'black people didn't really go in the city because in many cases they weren't actually welcome, and they'd be followed around in stores'. ${ }^{60}$ Another remembered that 'people would come into town and go "oh, where's the black community, where's the black people?", because they were just never seen in town. They couldn't get jobs in town anyway, other than when McDonald's started. ${ }^{\prime 61}$ Boundary markers could be very specific, and one of our witnesses identified a particular club on Duke Street that was 'the furthest into town that they [young black people] went'. ${ }^{62}$ Indeed, Seel Street and Duke Street seem to have served as a boundary zone more generally, because one retired policeman remembered different clubs on those streets catering for different, separate ethnic groups as customers. ${ }^{63}$ More often, the black Liverpudlians we interviewed spoke of clubs and bars on Upper Parliament Street; 'you could do like a pub crawl and it would take you all night just going up "Upper Parlie". ${ }^{64}$

Many of these issues remain unresolved, because recent regeneration efforts have focused on the docks and the business and leisure district of the city centre, with little strategic attention to the former residential and small business areas just inland, contributing to another phase of dislocation. ${ }^{65}$ The population of the old sailortown district is increasing again, thanks to large blocks of new flats on the side streets between Park Lane and the dock road. There is little connection, however, between these structures and the 1980s bungalows that replaced the Kent Gardens 'tennies', which were set out in mini-estates walled off from the old street pattern. All the current housing essentially turns its back on Park Lane, rather than having the street as its central focal point, and the district remains bereft of shops and other amenities.

\section{Nostalgia and ruins}

The relationship between memory and nostalgia is important to understanding the construction of past place. People who have seen their communities evolve in situ, without traumatic dislocation, have a different perspective from those who are remembering places that they abandoned long ago and which essentially exist only in memory and artefacts. Kerwin Klein suggests, as part of a broader discussion of the place of the Holocaust

59 M. Christian, 'The Fletcher Report 1930: a historical case study of contested black mixed heritage Britishness', Journal of Historical Sociology, 21 (2008), 213-41.

${ }^{60}$ Interview with Ray.

${ }^{61}$ Interview with Sandi.

62 Interview with Rita.

${ }^{63}$ Interview with John.

${ }^{64}$ Interview with Sandi.

65 J. Belchem, 'Port cities, cosmopolitanism and "otherness": the (mis-)representation of Liverpool', in J. Harris and R.J. Williams (eds.), Regenerating Culture and Society: Architecture, Art and Urban Style within the Global Politics of City-Branding (Liverpool, 2011). 
in the development of public memory studies, that 'memories not defined by trauma are likely to slide into nostalgia'. ${ }^{66}$ What, though, actually counts as trauma in this context? Again, moving discussion of public memory away from war and genocide into more commonplace events raises important questions, and a specific urban, locational focus gives nuances to the phenomenon, helping us to ask whether nostalgia is tied to place or to a more nebulous atmosphere or milieu.

Nostalgia is further complicated in Liverpool because the city's development in the past half-century has been far from linear. The most recent past is often regarded as positive, and an improvement on at least some of what came before. Many of our interviewees were ambivalent, freely mixing nostalgia with hard-headedness; they highlighted particularly interesting times but still contrasted them unfavourably with the current improvement in the city's fortunes. One woman thought that the Liverpool One development was much better than the 'dull' city centre of her youth. ${ }^{67}$ Another spoke fondly of the small community pubs that she had grown up around, but also recalled that St George's Hall and the museum district had seemed to her reserved for rich people: 'the world's wide open now, isn't it?' ${ }^{68}$ One interviewee spoke of happy memories as a child visiting the waterfront with her father, then sadness when she 'saw all that die', then pleasure that 'I'm seeing the city now being reborn. ${ }^{69}$

One important point is that few of our interviewees still live or work anywhere near the area in question. This sometimes gave particular clarity to their memories of the 1950s or 1960s, uncomplicated by detailed awareness of changes that had taken place since. On the other hand, their sense that the waterfront district changed suddenly in the 1970s may have been accentuated by the fact of their own, often rapid, departure from it. This does make it harder to compare the findings of this project with others that have studied longer-term change through the experiences of more settled communities that have, as it were, grown old in their own surroundings. ${ }^{70}$

Some places were remembered in similar terms by many interviewees, but very differently by a minority, and this is where ideas about the varying receptions and absorptions of popular memories are important. The Liverpool Overhead Railway, closed in 1956, was a common site of memory and nostalgia, usually nicknamed the 'The Dockers' Umbrella' because of the shelter it provided for dock workers walking up and down the dock road under its elevated tracks. For some who remembered standing on its windswept platforms very early in the morning, however, it was

\footnotetext{
66 Klein, 'On the emergence of memory', 139.

67 Interview with Val.

68 Interview with Barbara.

69 Interview with Rita.

${ }^{70}$ For example, Blokland, 'Bricks, mortar, memories'.
} 
'The Pneumonia Express'. ${ }^{71}$ Other common views found their doubters in the course of the interviews: one retired senior policeman was emphatic that he had not heard of anyone being arrested for prostitution on Lime Street in the 1970s, challenging a long-notorious image. ${ }^{72}$ Dock workers and seamen, who had access to the secret and sometimes fascinating world inside the dock wall, remembered such highlights as an impromptu quayside concert involving a piano on its way for export and some conveniently open casks of wine. ${ }^{73}$ Others, excluded from those spaces, thought that the recent opening-up of the barriers between the city and its river was a great transformation. ${ }^{7}$

Closely related to the issue of nostalgia is a question of the symbolism of ruins. ${ }^{75}$ The sheer scale of the nineteenth-century built environment in waterfront Liverpool was unusual, with the result that by the 1970s some of its ruins were spectacular. One journalist writing at the time described the rows of abandoned warehouses as 'megalithic', looking like 'coffins left landlocked by a vanished race of seagoing giants'. ${ }^{76}$ Nostalgia and sentimentality are tempered with a more practical sense of the experiences of those who lived or worked in some of these buildings, however. One seaman rejected the near-universal view that demolishing the Custom House after the war had been a crime, because 'my grandfather used to work in it, and he said everyone that worked in it hated it that much that they were delighted to see it come down, because it was draughty, it leaked, it was horrible'. ${ }^{77}$ The redundant Albert Dock warehouses, shortly to become a symbol of a whole new international pattern of waterfront regeneration, stood for a very different Liverpool when Alan Bleasdale featured their dereliction in 'George's last ride', an episode of Boys from the Blackstuff broadcast in $1982 .{ }^{78}$ To have George speak of hope in such a place seemed delusional, but Bleasdale was capturing the mix of despair and determination that characterized much of Liverpool's politics and popular world-view at the time.

Many of the ruins have been repaired or demolished in the last decade, removing physical evidence of some sites of memory and radically altering others. In addition, Liverpool's old waterfront districts have relatively few formal sites of memory in the official, commemorative sense. ${ }^{79}$ The Pierhead itself has become a memorial landscape in recent years, with powerful reminders of many aspects of the city's maritime past in statues,

71 Interview with Billy; workshop with seamen.

72 Interview with John.

73 Interview with Tony.

74 Interview with Stephen.

75 Mah, 'Memory, uncertainty and industrial ruination'.

76 R. Whittington-Egan, Liverpool: This Is My City (Liverpool, 1972), 39.

77 Workshop with seamen.

78 The British Film Institute's 'ScreenOnline Liverpool' website carries this episode and other clips.

79 N. Wood, Vectors of Memory: Legacies of Trauma in Postwar Europe (Oxford, 1999). 
plaques and artefacts. ${ }^{80}$ The old residential and light-industrial streets, however, lack such formal landmarks. Ironically, the Liverpool One retail and leisure complex has re-established the old street pattern in part of the area, enabling the ornamental iron gates of the Sailors' Home to be erected as a memorial close to their original location. ${ }^{81}$

Such developments will shortly enable a reappraisal of Liverpool's collective and community memories, as the public reception of formal memorials creates another layer in the evolving creation of a complex urban space. That complexity was part of Liverpool's transition through a series of different forms of urbanism, as a variety of elements - maritime, industrial, residential, commercial, leisure-oriented - shifted in relation to each other. Sites of memory in the waterfront zone of the 1950s and 1960s were the mundane places that represented these forces in the minds of the city's people. These everyday uses of spaces and places, the extent to which people pay attention to the places around them, and the degree to which those senses persist into memory are all under-researched aspects of urban studies. Some people are fascinated by their surroundings, and can recall decades later the detail of the buildings they worked in and the streets they walked. Others are much more instrumental, taking the shortest possible journey to work, only visiting the locations they specifically need to visit, and having little interest in the intervening spaces.

Urban historians naturally empathize with the former group, but need to accept that they are relatively unusual, and also that the latter group are neither stupid nor ignorant. Some of our most intriguing testimony came from people who had no recollection whatever of supposedly iconic buildings in the area. One of our interviewees did not remember the Sailors' Home, despite working on Paradise Street and (we were able to conclude) getting off the bus outside it every morning: even when prompted with photographs, she did not recognize it, although her memory of numerous other buildings in the close vicinity was detailed and accurate. ${ }^{82}$ Another interviewee was short on detail of the waterfront bars, candidly admitting that 'every pub was the same, very near, after you'd had a couple of scoops, know what I mean?'s3 Comparing the different sites-ofmemory maps generated by our interviewees allowed us to explore these nuances in a way that avoided a one-dimensional recollection of waterfront Liverpool.

80 J. Black, 'The image of the worker as hero in the public sculpture of Merseyside, c. 19121930', in Benbough-Jackson and Davies (eds.), Merseyside, 159-88; T. Cavanagh, Public Sculpture of Liverpool (Liverpool, 1997).

${ }^{81}$ D. Littlefield, Liverpool One: Remaking a City Centre (Chichester, 2009).

82 Interview with Rita.

83 Workshop with seamen. 


\section{Conclusion}

The collection of urban memories raises important questions about the changing nature of place, both physically and culturally. The process of building, demolishing and rebuilding in brick or stone or concrete is accompanied by a construction in memory. The consumption and reception of those memories is then part of the ongoing perception of place, not a separate process that happens after the memory is somehow 'complete' and ready for transmission. High levels of transience and mobility mean that often only a small proportion of the people who lived and worked in central urban districts in the mid-twentieth century continue to live there or have any reason to visit. Over time the area becomes a container of diverse individual memories, institutional and collective archives and traditions that may be difficult to relate to spaces on the ground. Continuing interaction between pasts and presents adds a memorial thread to the physical palimpsest of the city, which will sometimes be captured in official monuments, but often not. The diversity of views and recollections uncovered by the Mapping Memory project offers a valuable case-study in the need to continue revisiting and questioning the relationships between history, heritage, nostalgia and memory in urban space. 